\title{
Data report: rock magnetism of sediment from IODP Expedition 334 Sites U1378 and U1379'
}

\author{
Yoichi Usui $^{2}$
}

\section{Chapter contents}

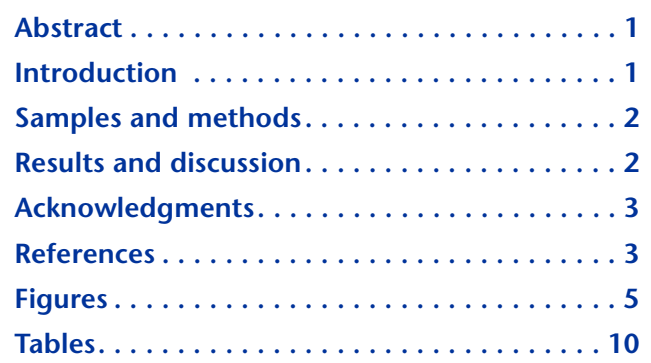

'Usui, Y., 2015. Data report: rock magnetism of sediment from IODP Expedition 334 Sites U1378 and U1379. In Vannucchi, P., Ujiie, K., Stroncik, N., Malinverno, A., and the Expedition 334 Scientists, Proc. IODP, 334: Tokyo (Integrated Ocean Drilling Program Management International, Inc.). doi:10.2204/iodp.proc.334.203.2015

2Department of Deep Earth Structure and Dynamics Research, Japan Agency for Marine-Earth Science and Technology, 2-15 Natushima-cho, Yokosuka 2370061, Japan. yoichi@jamstec.go.jp

\begin{abstract}
Magnetic properties were measured on sediments from Integrated Ocean Drilling Program Expedition 334 Sites U1378 and U1379. Rock magnetic parameters (i.e., saturation magnetization, $M_{\mathrm{s}}$; saturation remanence, $M_{\mathrm{rs}}$; coercivity, $H_{\mathrm{c}}$; and coercivity of remanence, $H_{\mathrm{cr}}$ ) do not show simple downcore trends, sediment columns exhibit sporadic occurrence of layers with high $M_{s}$, and other rock magnetic parameters are different in these layers than in the rest of the sediment. Specifically, samples with high $M_{\mathrm{s}}$ show reduced $M_{\mathrm{rs}} / M_{\mathrm{s}}$, indicating coarser magnetic grains in those samples. Thermomagnetic analyses suggest that low-Ti titanomagnetite is the main magnetic phase in samples with high $M_{\mathrm{s}}$, whereas other minerals contribute to the magnetic character of samples with low $M_{s}$. The variable occurrence of multiple magnetic phases should be considered in future paleomagnetic studies using sediments from Sites U1378 and U1379.
\end{abstract}

\section{Introduction}

Integrated Ocean Drilling Program (IODP) Expedition 334 drilled slope sediments on the Costa Rica subduction zone to understand the seismogenic processes in an erosional subduction zone. Evidence for tectonic erosion in this area back to $\sim 16$ Ma has been reported (Vannucchi et al., 2001). One of the primary goals of the expedition was to reveal the time evolution of tectonic erosion in this area, so dating of the sediment is of great importance. Although preliminary biostratigraphy and magnetostratigraphy suggest very high sedimentation rates $(51.6-23.6 \mathrm{~cm} / \mathrm{ky}$ for Site U1378 and 103.5-16.0 cm/ky for Site U1379; see the "Expedition 334 summary" chapter [Expedition 334 Scientists, 2012a]), shipboard paleomagnetic measurements could not fully isolate primary remanence because of severe drilling-related overprint, and complete magnetostratigraphy awaits detailed demagnetization experiments.

Rock magnetic characterization of sediments is essential to the interpretation of paleomagnetic recordings. For example, it is widely known that diagenetic reduction of magnetic iron oxide degrades the magnetic recording in sedimentary environments where bacterial reduction of sulfate occurs (e.g., Karlin and Levi, 1983; Berner, 1981; Tarduno, 1994; Rowan et al., 2009; Dewangan et al., 2013). Importantly, diagenetic reduction of iron oxide does 
not always follow the present-day chemical profile of pore water; past migration of the chemical reaction front could produce complex zonation in the diagenetic product (Rowan et al., 2009; Dewangan et al., 2013) that in turn results in complex smoothing of the paleomagnetic record (Rowan et al., 2009). Sediments from Sites U1378 and U1379 contain pyrite, indicating sulfate reduction has also taken place in those sediments. To help constrain the impact of such processes on paleomagnetic recordings, I conducted rock magnetic measurements on sediment samples from Sites U1378 and U1379.

\section{Samples and methods}

Cube samples were taken aboard the R/V JOIDES Resolution from cores from Holes U1378B and U1379C. The cube samples used in this study were subjected to alternating field (AF) demagnetization either on ship or on shore. From each cube, $\sim 0.5 \mathrm{~g}$ of sediment was sampled. Those samples were dried and gently powdered and then measured for magnetic hysteresis and thermomagnetic curves.

Hysteresis measurements were performed using a vibrating sample magnetometer (VSM, Princeton Measurements Inc.). Powder samples of $\sim 0.1 \mathrm{~g}$ placed in gelatin capsules were measured. Major hysteresis loops were measured using a maximum field of $0.5 \mathrm{~T}$, and I determined saturation magnetization $\left(M_{\mathrm{s}}\right)$, saturation remanence $\left(M_{\mathrm{rs}}\right)$, and coercivity $\left(H_{\mathrm{c}}\right)$ after correction for paramagnetic contribution. Coercivity of remanence $\left(H_{\mathrm{cr}}\right)$ was determined from backfield demagnetization of saturation magnetization. For selected samples, first-order reversal curves (FORCs) (Pike et al., 1999) were also measured. FORC data were analyzed using FORCinel software (Harrison and Feinberg, 2008).

Thermomagnetic analyses were conducted on initial magnetic susceptibility measurements using a Kappabridge KLY 4 (Agico). The temperature dependence of initial susceptibility, $\chi(\mathrm{T})$, was measured upon heating from $-192^{\circ} \mathrm{C}$ to $15^{\circ} \mathrm{C}$. Then the $\chi(\mathrm{T})$ curves were measured upon cycling from room temperature to $700^{\circ} \mathrm{C}$ in air.

\section{Results and discussion}

Downcore variations of hysteresis parameters are shown in Figure F1. Hysteresis parameters for Site U1378 are shown in Table T1 and for Site U1379 in Table T2. The variations of $M_{\mathrm{s}}$ closely match that of magnetic susceptibility measured on ship (see the "Site U1378" and "Site U1379" chapters [Expedition 334 Scientists, 2012b, 2012c]), showing sporadic occurrence of layers with high values. $M_{\mathrm{rs}} / M_{\mathrm{s}}$ slightly increases with depth with considerable scatter. Samples 334-U1379C-49X-3W, 132-134 cm, and 334U1479C-50X-1W, 1341-136 cm, show exceptionally high $M_{\mathrm{rs}} / M_{\mathrm{s}}$. These samples also show elevated coercivity, indicating the presence of fine-grained magnetic minerals. $H_{\mathrm{cr}} / H_{\mathrm{c}}$ of Site U1379 slightly decreases with depth, except for the high value of Sample 334U1379C-6H-4W, 100-102 cm, and low values of the samples mentioned above. $H_{\mathrm{cr}} / H_{\mathrm{c}}$ of Site U1378 does not show a noticeable trend with depth.

The interrelationships among hysteresis parameters were analyzed using Day plots (Day et al., 1977; Dunlop, 2002), as shown in Figure F2. Most samples plot in a pseudosingle-domain (PSD) region, except for Samples 334-U1379C-49X-3W, 132-134 cm, and 334-U1479C-50X-1W, 134-136 cm, which plot in a single-domain (SD) region. Samples exhibit departure from the theoretical mixing line between SD and coarse-grained, multidomain (MD) titanomagnetite, indicating the presence of superparamagnetic (SP) grains and/or multiple magnetic minerals with distinct coercivities (Tauxe et al., 1996; Dunlop, 2002).

For Site U1378, the departure from the SD-MD mixing line of titanomagnetite observed in Day plots shows some correlation with depth (Fig. F2A), where samples from shallow depths tend to lie close to the SD-MD mixing line. There are exceptions; samples from above 100 meters below seafloor (mbsf) depart from the mixing line, and some samples from 300400 mbsf plot near to the mixing line. $M_{\mathrm{s}}$ values more closely correlate with the departure from the SD-MD mixing line, where high $M_{\mathrm{s}}$ samples plot close to the mixing line (Fig. F2C). The same is true for Site U1379 (Figs. F2B, F2C). For Site U1379, samples from the uppermost $100 \mathrm{~m}$ plot toward the coarse end of the PSD region. The dominant control of $M_{\mathrm{s}}$ on the Day plot parameters $\left(M_{\mathrm{rs}} / M_{\mathrm{s}}\right.$ and $\left.H_{\mathrm{cr}} / H_{\mathrm{c}}\right)$ is clearly seen by plotting these parameters against $M_{\mathrm{s}}$ (Fig. F3). For both sites, $M_{\mathrm{rs}} / M_{\mathrm{s}}$ is systematically low for samples with $M_{\mathrm{s}}>0.05 \mathrm{Am}^{2} / \mathrm{kg}$, whereas $H_{\mathrm{cr}} /$ $H_{\mathrm{c}}$ is not clearly related to $M_{\mathrm{s}}$, resulting in a departure from the SD-MD mixing line in low $M_{\mathrm{s}}$ samples.

FORC measurements were conducted on samples from Site U1379 only and are shown in FORC diagrams (Roberts et al., 2000) (Fig. F4). The horizontal axis of a FORC diagram $\left(H_{\mathrm{c}}\right)$ represents coercivity, and the vertical axis $\left(H_{\mathrm{u}}\right)$ reflects magnetostatic interactions (e.g., Muxworthy and Williams, 2005). Some samples show FORC distributions with low $H_{\mathrm{c}}$ peak and spread along $H_{\mathrm{u}}$, whereas others show broad $H_{\mathrm{c}}$ distribution extended to high coercivity with smaller spread in $H_{\mathrm{u}}$. Although sample numbers are limited, 
the latter seems to correspond to samples that plot toward the finer (SD) side in Day plots.

Thermomagnetic experiments were conducted for two samples, 334-U1379C-13H-4W, 34-36 cm, and 334-U1379C-57X-5W, 111-113 cm (Fig. F5). These samples show $M_{\mathrm{s}}$ values of $8.67 \mathrm{mAm}^{2} / \mathrm{kg}$ and 151 $\mathrm{mAm}^{2} / \mathrm{kg}$, respectively. These samples were chosen to represent low $M_{\mathrm{s}}$ and high $M_{\mathrm{s}}$ samples, respectively. Sample 334-U1379C-13H-4W, 34-36 cm (low $\left.M_{\mathrm{s}}\right)$, exhibits an increase in $\chi$ upon heating from $\sim 375^{\circ} \mathrm{C}$ followed by a decrease to zero at $\sim 580^{\circ} \mathrm{C}$. The cooling curve is more elevated than the heating curve. Sample 334-U1379C-57X-5W, 111-113 cm (high $M_{\mathrm{s}}$ ), shows an increase in $\chi$ upon heating at around $-160^{\circ} \mathrm{C}$ to $-150^{\circ} \mathrm{C}$, indicating the presence of the Verwey transition of low-Ti titanomagnetite (Verwey, 1939). The heating curve of the sample suggests the presence of the magnetic phase with a $\mathrm{Cu}$ rie temperature of $\sim 580^{\circ} \mathrm{C}$, also indicating the presence of magnetite. The cooling curve is more elevated than the heating curve, but the change is smaller than that in the other sample.

The thermomagnetic curves of the high $M_{\mathrm{s}}$ sample and the hysteresis parameters lying on the SD-MD mixing line suggest that the main magnetic phase in samples with high $M_{s}$ is low-Ti titanomagnetite. The magnetic phases in samples with low $M_{s}$ are not clearly resolved, but the departure of hysteresis parameters from the SD-MD mixing line and the absence of the Verwey transition indicate that they contain magnetic minerals other than low-Ti titanomagnetite. Identification of magnetic minerals in the low $M_{s}$ samples will be crucial for future paleomagnetic studies.

\section{Acknowledgments}

This research used samples and data provided by Integrated Ocean Drilling Program (IODP). I thank Xixi Zhao for his discussion and IODP for receipt of samples. Part of this study was performed under the cooperative research program of Center for Advanced Marine Core Research (CMCR), Kochi University (11B045; Japan). I thank Yuhji Yamamoto and Kazuto Kodama for their assistance at CMCR.

\section{References}

Berner, R.A., 1981. A new geochemical classification of sedimentary environments. Journal of Sedimentary Research, 51(2):359-365. doi:10.1306/212F7C7F-2B24-11D78648000102C1865D

Day, R., Fuller, M., and Schmidt, V.A., 1977. Hysteresis properties of titanomagnetites: grain-size and compositional dependence. Physics of the Earth and Planetary
Interiors, 13(4):260-267. doi:10.1016/00319201(77)90108-X

Dewangan, P., Basavaiah, N., Badesab, F.K., Usapkar, A., Mazumdar, A., Joshi, R., and Ramprasad, T., 2013. Diagenesis of magnetic minerals in a gas hydrate/cold seep environment off the Krishna-Godavari basin, Bay of Bengal. Marine Geology, 340:57-70. doi:10.1016/j.margeo.2013.04.016

Dunlop, D.J., 2002. Theory and application of the Day plot $\left(M_{\mathrm{rs}} / M_{\mathrm{s}}\right.$ versus $\left.H_{\mathrm{cr}} / H_{\mathrm{c}}\right), 1$. Theoretical curves and tests using titanomagnetite data. Journal of Geophysical Research: Solid Earth, 107(B3):2056. doi:10.1029/ 2001JB000486

Expedition 334 Scientists, 2012a. Expedition 334 summary. In Vannucchi, P., Ujiie, K., Stroncik, N., Malinverno, A., and the Expedition 334 Scientists, Proc. IODP, 334: Tokyo (Integrated Ocean Drilling Program Management International, Inc.). doi:10.2204/

iodp.proc.334.101.2012

Expedition 334 Scientists, 2012b. Site U1378. In Vannucchi, P., Ujiie, K., Stroncik, N., Malinverno, A., and the Expedition 334 Scientists, Proc. IODP, 334: Tokyo (Integrated Ocean Drilling Program Management International, Inc.). doi:10.2204/iodp.proc.334.103.2012

Expedition 334 Scientists, 2012c. Site U1379. In Vannucchi, P., Ujiie, K., Stroncik, N., Malinverno, A., and the Expedition 334 Scientists, Proc. IODP, 334: Tokyo (Integrated Ocean Drilling Program Management International, Inc.). doi:10.2204/iodp.proc.334.104.2012

Harrison, R.J., and Feinberg, J.M., 2008. FORCinel: an improved algorithm for calculating first-order reversal curve distributions using locally weighted regression smoothing. Geochemistry, Geophysics, Geosystems, 9(5):Q05016. doi:10.1029/2008GC001987

Karlin, R., and Levi, S., 1983. Diagenesis of magnetic minerals in recent hemipelagic sediments. Nature, 303(5915):327-330. http://dx.doi.org/10.1038/ $303327 \mathrm{a} 0$

Muxworthy, A., and Williams, W., 2005. Magnetostatic interaction fields in first-order-reversal-curve diagrams. Journal of Applied Physics, 97:063905. doi:10.1063/ 1.1861518

Pike, C.R., Roberts, A.P., and Verosub, K.L., 1999. Characterizing interactions in fine magnetic particle systems using first order reversal curves. Journal of Applied Physics, 85(9):6660-6667. doi:10.1063/1.370176

Roberts, A.P., Pike, C.R., and Verosub, K.L., 2000. Firstorder reversal curve diagrams: a new tool for characterizing the magnetic properties of natural samples. Journal of Geophysical Research: Solid Earth, 105(B12):2846128475. doi:10.1029/2000JB900326

Rowan, C.J., Roberts, A.P., and Broadbent, T., 2009. Reductive diagenesis, magnetite dissolution, greigite growth and paleomagnetic smoothing in marine sediments: a new view. Earth and Planetary Science Letters, 277(12):223-235. http://dx.doi.org/10.1016/ j.epsl.2008.10.016

Tarduno, J.A., 1994. Temporal trends of magnetic dissolution in the pelagic realm: gauging paleoproductivity? 
Earth and Planetary Science Letters, 123(1-3):39-48. doi:10.1016/0012-821X(94)90255-0

Tauxe, L., Mullender, T.A.T., and Pick, T., 1996. Potbellies, wasp-waists, and superparamagnetism in magnetic hysteresis. Journal of Geophysical Research: Solid Earth, 101(B1):571-583. doi:10.1029/95JB03041

Vannucchi, P., Scholl, D.W., Meschede, M., and McDougall-Reid, K., 2001. Tectonic erosion and consequent collapse of the Pacific margin of Costa Rica: combined implications from ODP Leg 170, seismic offshore data, and regional geology of the Nicoya Peninsula. Tectonics, 20(5):649-668. doi:10.1029/2000TC001223

Verwey, E.J.W., 1939. Electron conduction of magnetite $\left(\mathrm{Fe}_{3} \mathrm{O}_{4}\right)$ and its transition point at low temperatures. Nature, 144(3642):327-328. doi:10.1038/144327b0

Initial receipt: 11 December 2014

Acceptance: 13 May 2015

Publication: 17 September 2015

MS 334-203 
Figure F1. Depth variation of rock magnetic parameters, Holes U1378B and U1379C. $M_{\mathrm{s}}=$ saturation magnetization, $M_{\mathrm{rs}}=$ saturation remanence, $H_{\mathrm{c}}=$ coercivity, $H_{\mathrm{cr}}=$ coercivity of remanence. Sample 334-U1379C-6H-4W, 99-101 cm, was out of the plot range.

\section{U1378B}
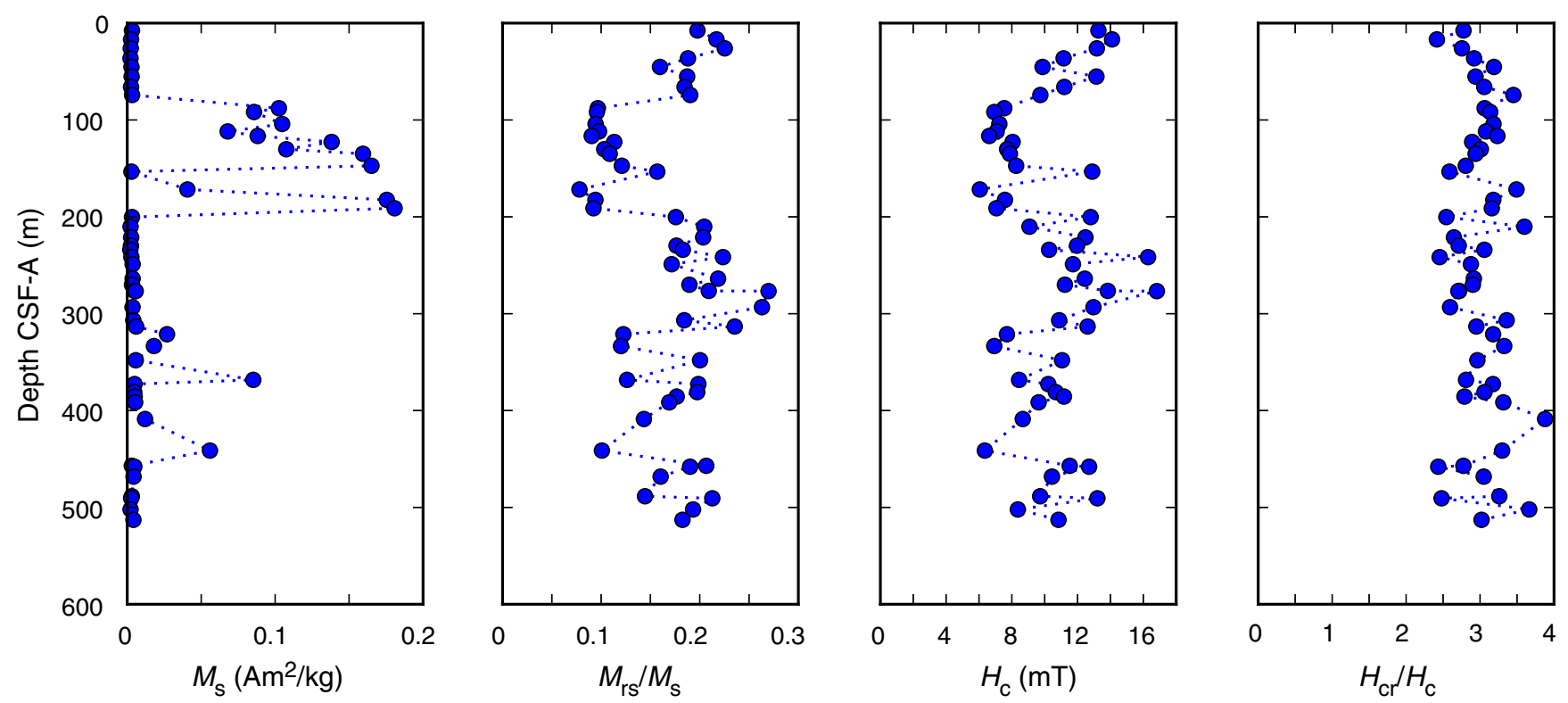

\section{U1379C}
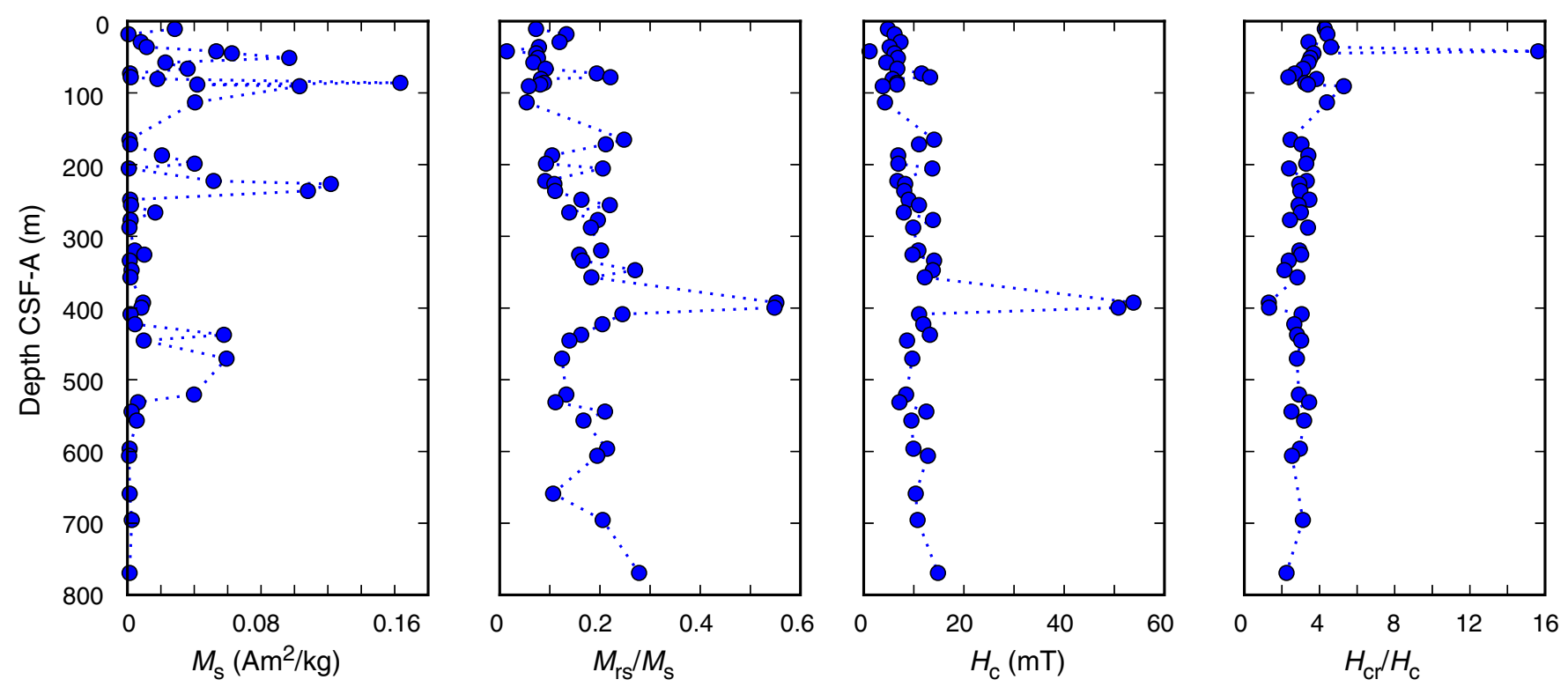
Figure F2. Day plots showing interrelationship among rock magnetic parameters, Holes U1378B and U1379C. Magnetic domain boundaries defined by Day et al. (1977) are shown. Dotted lines = theoretical single-domain (SD)-multidomain (MD) mixing line of titanomagnetite (Dunlop, 2002). PSD = pseudosingle domain. Color bars indicate (A, B) depth or (C, D) saturation magnetization. Note that the color scales for C and D are inverted relative to those for $\mathrm{A}$ and $\mathrm{B}$.

A $\quad$ U1378B

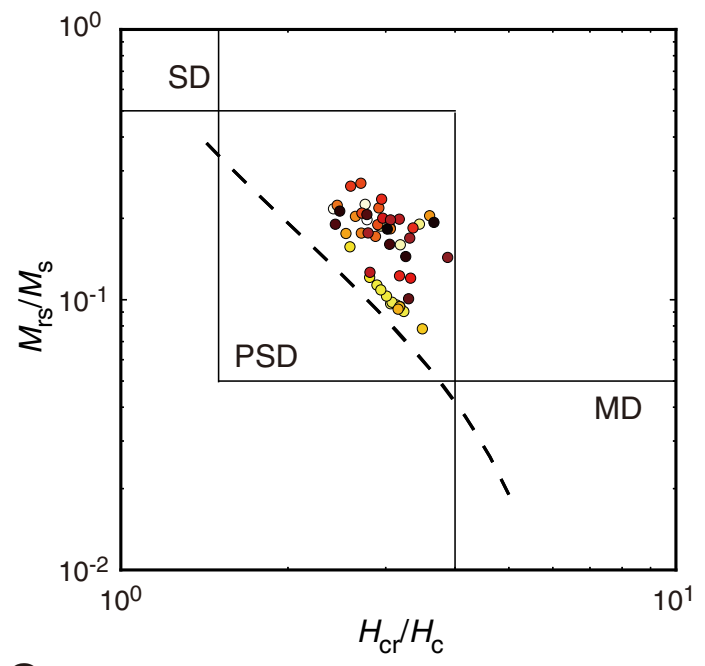

C

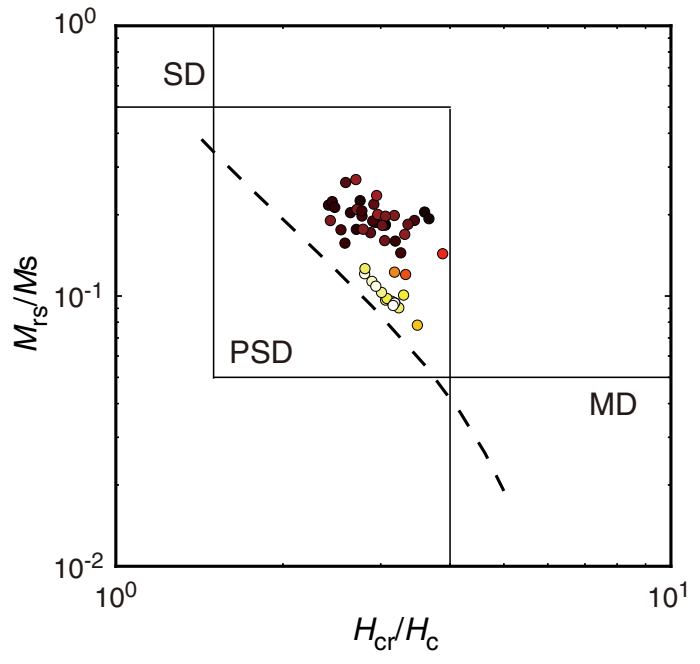

B U1379C

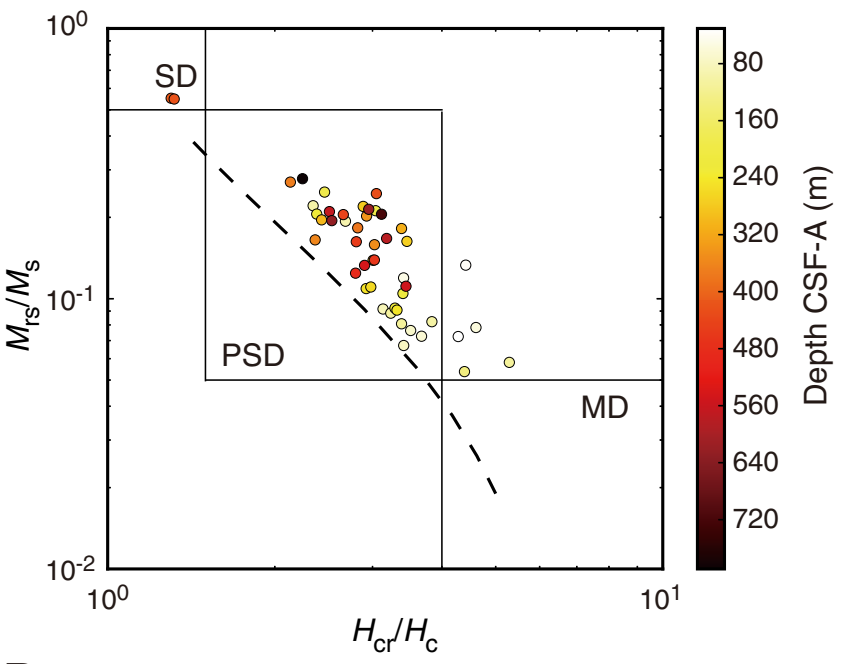

D
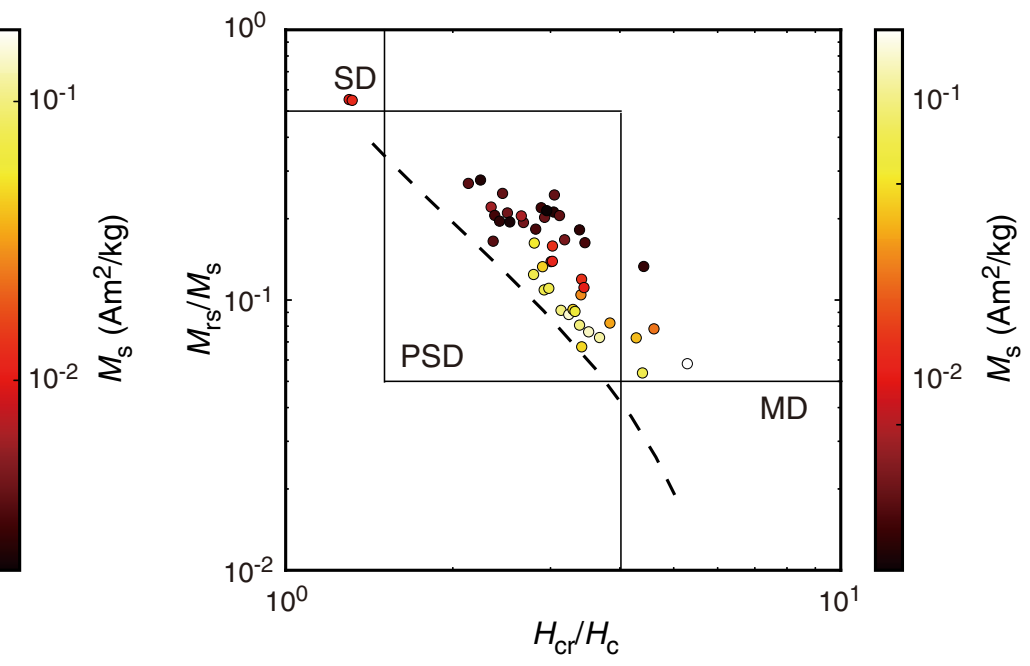
Figure F3. Variation of rock magnetic parameters with saturation magnetization $\left(M_{\mathrm{s}}\right)$, Holes U1378B and U1379C. Inset for each figure shows magnified view for $M_{\mathrm{s}}$ smaller than $0.01 \mathrm{Am}^{2} / \mathrm{kg}$. $M_{\mathrm{rs}}=$ saturation remanence. Samples 334-U1379C-6H-4W, 99-101 cm, 49X-3W, 131-134 cm, and 50X-1W, 133-135 cm, are out of the plot range.

\section{A}

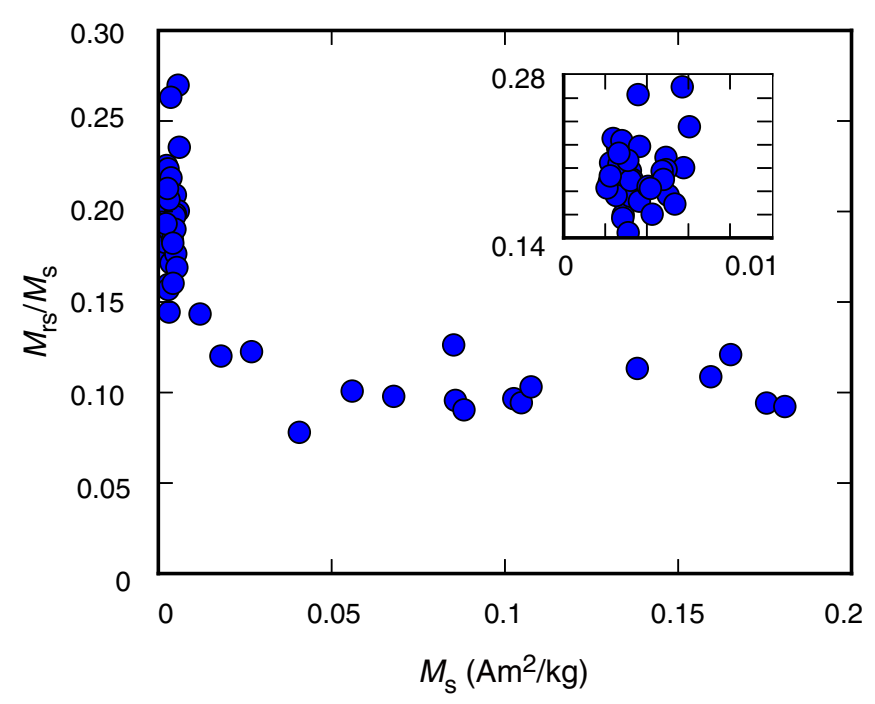

C

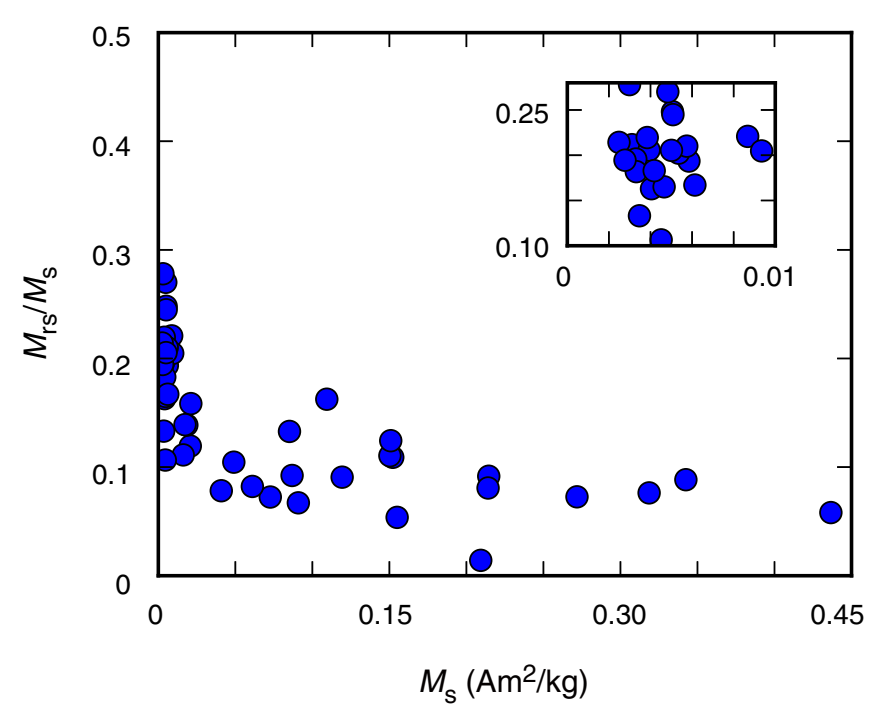

B

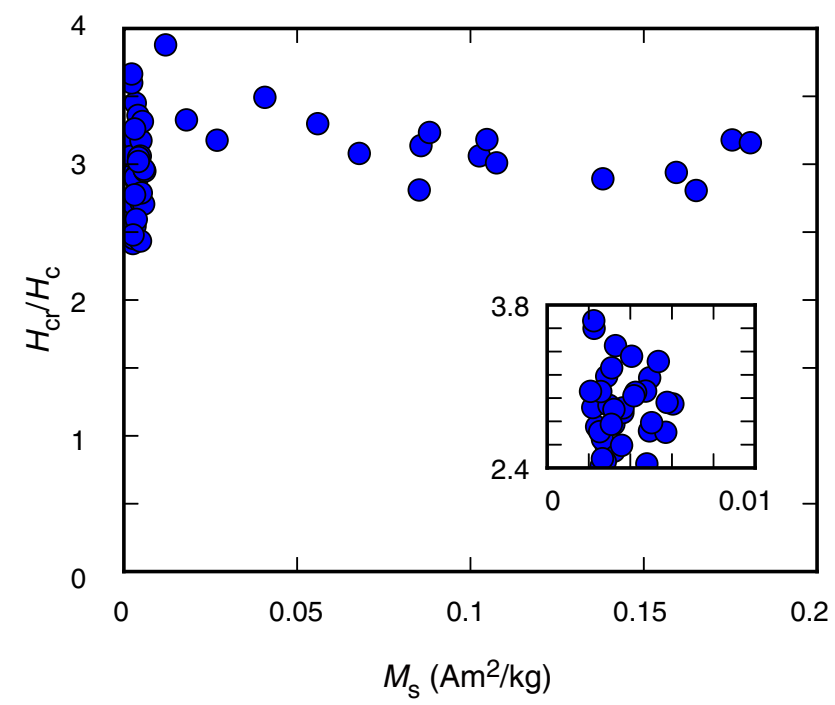

D

U1379C

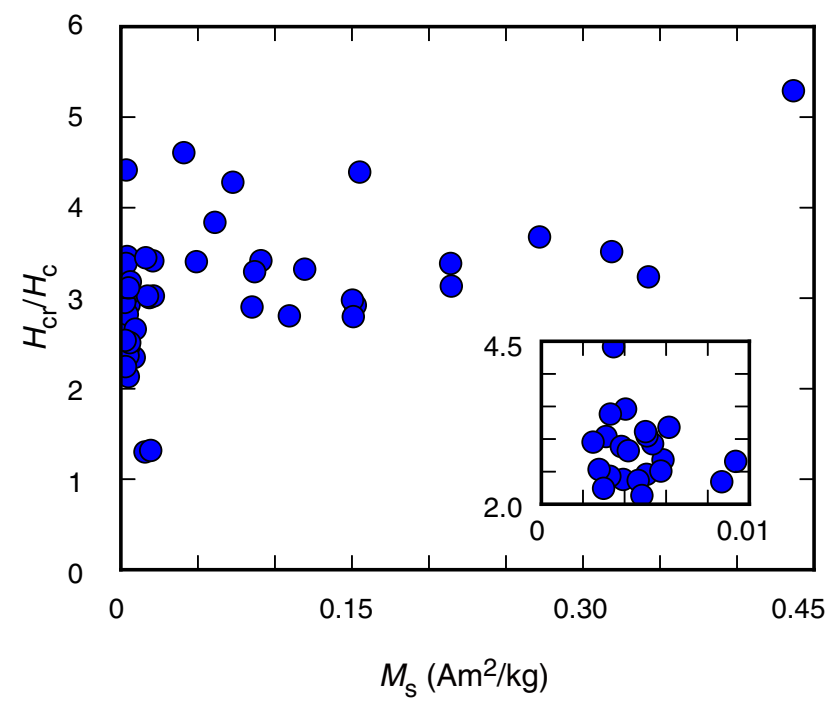


Figure F4. A-D. FORC diagrams for Hole U1379C samples shown in arbitral unit. Smoothing factors (SF) were used to calculate the diagrams. E. Day plot of samples used in the FORC analysis. Letters = corresponding FORC diagram.

\section{A}
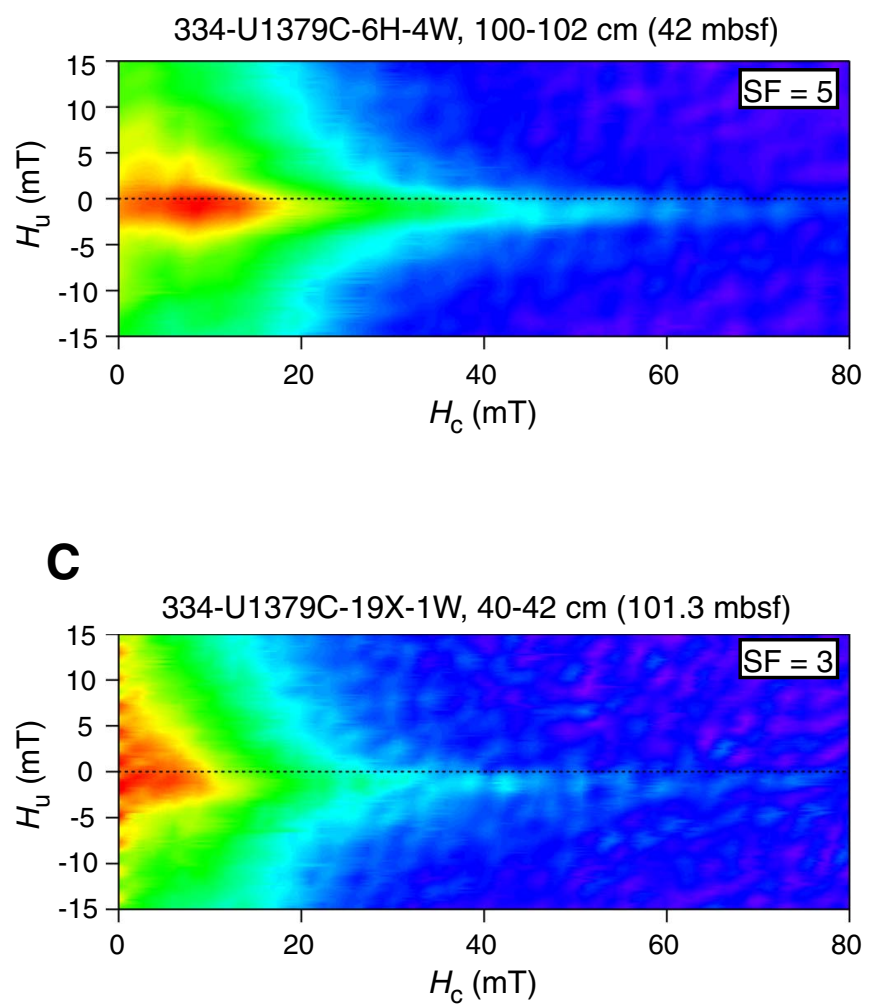

E

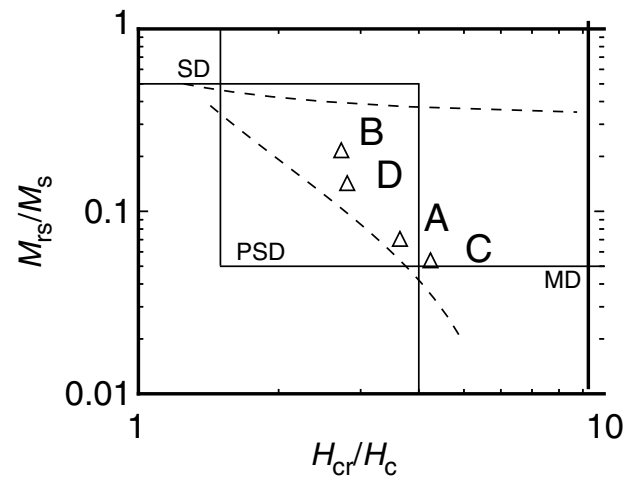

B
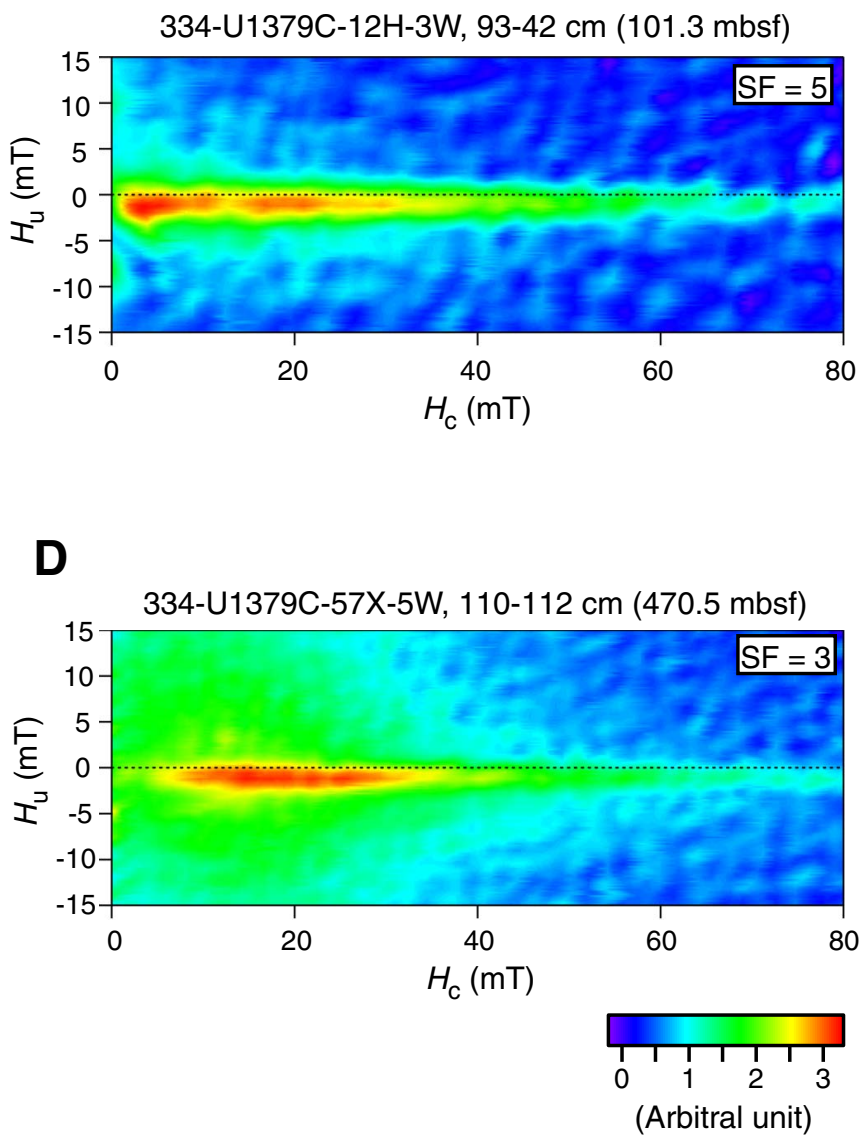
Figure F5. Thermomagnetic analysis, Hole U1379C. A, B. Temperature dependence of magnetic susceptibility, $\chi$. Data are normalized by room temperature susceptibility before treatment $\left(\chi_{0}\right)$. Green circles $=$ heating from $-92^{\circ} \mathrm{C}$, red circles $=$ heating to $700^{\circ} \mathrm{C}$, blue circles $=$ cooling from $700^{\circ} \mathrm{C}$. C. Day plot of samples used in thermomagnetic analysis. Letters $=$ corresponding thermomagnetic curves.

A

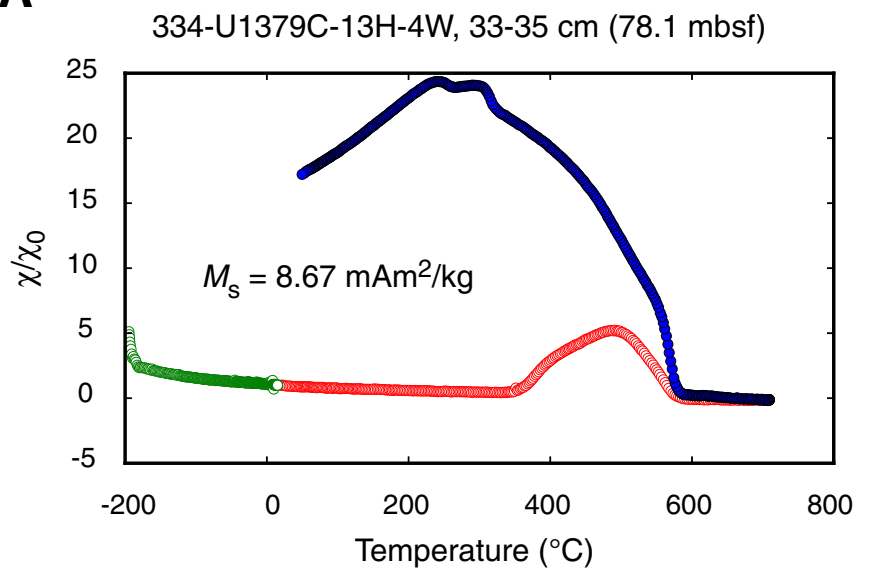

B

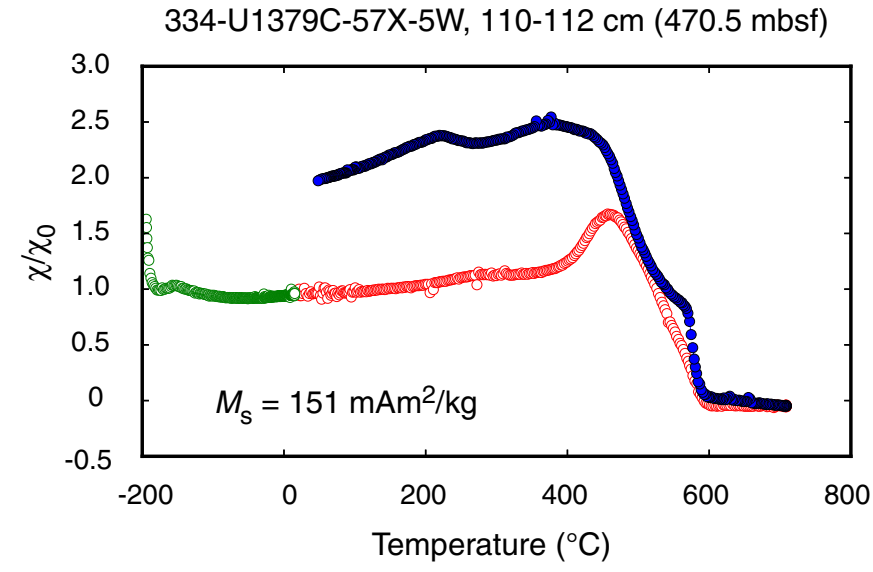

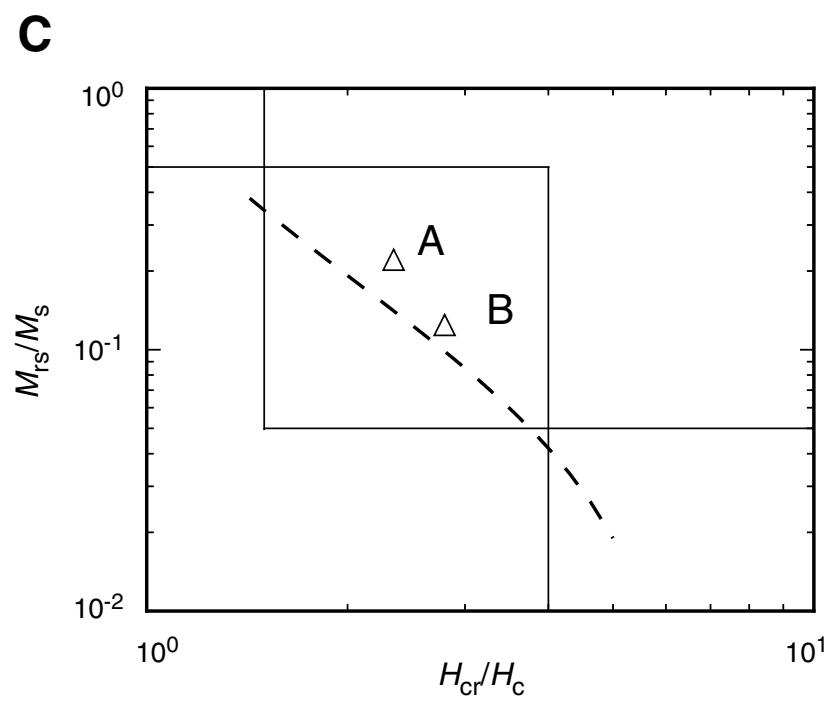


Table T1. Hysteresis parameters, Site U1378.

\begin{tabular}{|c|c|c|c|c|c|}
\hline $\begin{array}{l}\text { Core, section, } \\
\text { interval }(\mathrm{cm})\end{array}$ & $\begin{array}{l}\text { Top depth } \\
\text { CSF-A (m) }\end{array}$ & $\begin{array}{c}M_{\mathrm{s}} \\
(\mathrm{mAm} / \mathrm{kg})\end{array}$ & $\begin{array}{c}M_{\mathrm{rs}} \\
\left(\mathrm{mAm} \mathrm{m}^{2} / \mathrm{kg}\right)\end{array}$ & $\begin{array}{c}H_{\mathrm{c}} \\
(\mathrm{mT})\end{array}$ & $\begin{array}{c}H_{\mathrm{cr}} \\
(\mathrm{mT})\end{array}$ \\
\hline \multicolumn{6}{|l|}{ 334-U1378B- } \\
\hline $2 \mathrm{H}-2,78-80$ & 7.58 & 3.21 & 0.63 & 13.3 & 36.8 \\
\hline $3 \mathrm{H}-2,51-53$ & 16.81 & 2.60 & 0.56 & 14.1 & 34.1 \\
\hline $4 \mathrm{H}-2,114-116$ & 26.05 & 2.38 & 0.54 & 13.2 & 36.3 \\
\hline $5 \mathrm{H}-2,104-106$ & 36.36 & 2.19 & 0.41 & 11.1 & 32.5 \\
\hline $6 \mathrm{H}-2,44-46$ & 45.24 & 2.86 & 0.46 & 9.9 & 31.5 \\
\hline $7 \mathrm{H}-2,85-87$ & 55.15 & 2.97 & 0.56 & 13.1 & 38.6 \\
\hline $8 \mathrm{H}-4,47-49$ & 65.91 & 2.58 & 0.48 & 11.2 & 34.2 \\
\hline $9 \mathrm{H}-2,92-94$ & 74.22 & 3.29 & 0.63 & 9.7 & 33.6 \\
\hline $10 \mathrm{H}-5,63-65$ & 87.85 & 103 & 9.9 & 7.54 & 23.1 \\
\hline $11 \mathrm{H}-2,67-69$ & 91.77 & 85.7 & 8.20 & 6.93 & 21.8 \\
\hline $13 \mathrm{H}-2,63-65$ & 104.13 & 105 & 9.9 & 7.24 & 23.0 \\
\hline $14 \mathrm{H}-2,64-66$ & 111.84 & 67.9 & 6.65 & 7.08 & 21.8 \\
\hline $15 \mathrm{H}-1,71-73$ & 116.51 & 88.2 & 7.98 & 6.62 & 21.4 \\
\hline $16 \mathrm{H}-2,75-77$ & 122.70 & 138 & 15.7 & 8.05 & 23.3 \\
\hline $17 X-2,91-93$ & 130.21 & 108 & 11.1 & 7.71 & 23.2 \\
\hline $18 \mathrm{H}-2,73-75$ & 134.93 & 159 & 17.3 & 7.88 & 23.2 \\
\hline $19 X-4,94-96$ & 147.28 & 165 & 20.0 & 8.26 & 23.2 \\
\hline $20 X-2,84-86$ & 153.37 & 2.84 & 0.45 & 12.9 & 33.3 \\
\hline $22 X-1,44-46$ & 171.74 & 40.7 & 3.17 & 6.05 & 21.1 \\
\hline $23 X-2,78-80$ & 182.48 & 176 & 16.5 & 7.58 & 24.1 \\
\hline $24 X-2,43-45$ & 191.12 & 181 & 16.7 & 7.06 & 22.3 \\
\hline $25 X-1,75-77$ & 200.25 & 3.22 & 0.57 & 12.8 & 32.6 \\
\hline 26X-1, 99-101 & 210.19 & 2.26 & 0.46 & 9.1 & 32.7 \\
\hline $27 X-3,96-98$ & 221.23 & 2.66 & 0.54 & 12.5 & 33.0 \\
\hline $28 X-2,66-68$ & 229.76 & 2.53 & 0.45 & 12.0 & 32.4 \\
\hline $29 X-1,21-23$ & 234.01 & 2.09 & 0.38 & 10.3 & 31.4 \\
\hline $30 \times-3,34-36$ & 241.59 & 2.80 & 0.63 & 16.3 & 40.0 \\
\hline $31 X-2,52-54$ & 248.92 & 3.64 & 0.62 & 11.7 & 33.7 \\
\hline $32 X-6,70-72$ & 263.85 & 3.65 & 0.80 & 12.4 & 36.3 \\
\hline $33 \times-3,117-119$ & 270.08 & 3.21 & 0.61 & 11.2 & 32.6 \\
\hline $34 X-1,67-69$ & 276.47 & 4.92 & 1.03 & 13.8 & 37.6 \\
\hline $34 X-1,91-93$ & 276.71 & 5.70 & 1.54 & 16.8 & 45.5 \\
\hline $35 X-6,89-91$ & 293.29 & 3.58 & 0.94 & 13.0 & 33.6 \\
\hline $37 X-2,50-52$ & 306.80 & 4.06 & 0.75 & 10.9 & 36.6 \\
\hline $38 X-3,93-95$ & 313.23 & 6.05 & 1.42 & 12.6 & 37.2 \\
\hline $39 X-5,72-74$ & 321.22 & 26.9 & 3.30 & 7.70 & 24.5 \\
\hline $40 X-7,98-100$ & 333.43 & 18.1 & 2.17 & 6.93 & 23.1 \\
\hline $42 X-4,72-74$ & 348.08 & 5.77 & 1.16 & 11.1 & 32.8 \\
\hline $45 X-2,25-27$ & 368.35 & 85.2 & 10.8 & 8.44 & 23.7 \\
\hline $46 X-1,107-109$ & 372.67 & 4.93 & 0.98 & 10.2 & 32.4 \\
\hline $47 X-3,128-130$ & 380.98 & 4.73 & 0.93 & 10.7 & 32.7 \\
\hline $48 X-3,96-98$ & 385.58 & 5.02 & 0.89 & 11.2 & 31.2 \\
\hline $49 X-1,93-95$ & 391.53 & 5.35 & 0.90 & 9.6 & 31.9 \\
\hline $50 X-7,23-25$ & 408.76 & 12.0 & 1.73 & 8.67 & 33.6 \\
\hline $54 X-3,62-64$ & 441.32 & 55.9 & 5.64 & 6.36 & 21.0 \\
\hline $56 X-1,35-37$ & 457.05 & 3.09 & 0.64 & 11.5 & 32.0 \\
\hline $56 X-2,40-42$ & 458.00 & 4.79 & 0.91 & 12.7 & 30.9 \\
\hline $57 X-2,44-46$ & 468.24 & 4.25 & 0.68 & 10.4 & 31.8 \\
\hline $59 X-3,126-128$ & 488.49 & 3.10 & 0.45 & 9.7 & 31.7 \\
\hline $59 X-5,62-64$ & 490.60 & 2.66 & 0.57 & 13.2 & 32.7 \\
\hline $60 X-6,60-62$ & 502.14 & 2.24 & 0.43 & 8.37 & 30.7 \\
\hline $62 X-3,83-85$ & 512.84 & 4.17 & 0.76 & 10.8 & 32.7 \\
\hline
\end{tabular}

$M_{\mathrm{s}}=$ saturation magnetization, $M_{\mathrm{rs}}=$ saturation remanence, $H_{\mathrm{c}}=$ coercivity, $H_{\mathrm{cr}}=$ coercivity of remanence . 
Table T2. Hysteresis parameters, Site U1379.

\begin{tabular}{|c|c|c|c|c|c|}
\hline $\begin{array}{l}\text { Core, section, } \\
\text { interval }(\mathrm{cm})\end{array}$ & $\begin{array}{l}\text { Top depth } \\
\text { CSF-A (m) }\end{array}$ & $\begin{array}{c}M_{\mathrm{s}} \\
(\mathrm{mAm} / \mathrm{kg})\end{array}$ & $\begin{array}{c}M_{\mathrm{rs}} \\
\left(\mathrm{mAm}^{2} / \mathrm{kg}\right)\end{array}$ & $\begin{array}{c}H_{\mathrm{c}} \\
(\mathrm{mT})\end{array}$ & $\begin{array}{c}H_{\mathrm{cr}} \\
(\mathrm{mT})\end{array}$ \\
\hline \multicolumn{6}{|l|}{ 334-U1379C- } \\
\hline $2 \mathrm{H}-3,111-113$ & 10.81 & 72.7 & 5.27 & 4.82 & 20.6 \\
\hline $3 \mathrm{H}-2,46-48$ & 18.16 & 3.47 & 0.46 & 6.15 & 27.2 \\
\hline $4 \mathrm{H}-4,39-41$ & 29.09 & 20.7 & 2.48 & 7.34 & 25.0 \\
\hline $5 \mathrm{H}-4,134-136$ & 36.04 & 40.9 & 3.20 & 5.18 & 23.8 \\
\hline $6 \mathrm{H}-4,100-102$ & 42.00 & 209 & 2.96 & 1.17 & 18.2 \\
\hline $7 \mathrm{H}-2,81-83$ & 44.81 & 272 & 19.7 & 6.14 & 22.6 \\
\hline $8 \mathrm{H}-2,60-62$ & 51.20 & 319 & 24.3 & 6.81 & 23.9 \\
\hline $9 \mathrm{H}-2,60-62$ & 57.60 & 90.9 & 6.10 & 4.50 & 15.4 \\
\hline $11 \mathrm{H}-2,126-127$ & 66.26 & 214 & 19.6 & 6.71 & 21.0 \\
\hline $12 \mathrm{H}-4,67-69$ & 72.87 & 5.85 & 1.13 & 11.6 & 31.0 \\
\hline $13 \mathrm{H}-4,33-35$ & 78.13 & 8.67 & 1.92 & 13.2 & 31.0 \\
\hline $14 \mathrm{H}-2,36-8$ & 80.56 & 61.0 & 5.02 & 5.76 & 22.1 \\
\hline $15 \mathrm{H}-3,89-91$ & 86.04 & 342 & 30.3 & 6.62 & 21.4 \\
\hline $16 \mathrm{H}-2,31-33$ & 88.31 & 214 & 17.3 & 6.64 & 22.5 \\
\hline $17 \mathrm{H}-1,48-50$ & 90.68 & 437 & 25.4 & 3.80 & 20.1 \\
\hline $20 X-2,98-100$ & 113.18 & 155 & 8.33 & 4.24 & 18.6 \\
\hline $25 X-4,101-103$ & 165.21 & 5.06 & 1.25 & 14.0 & 34.5 \\
\hline $26 X-2,67-69$ & 171.67 & 3.11 & 0.66 & 11.0 & 33.5 \\
\hline $27 X-6,31-33$ & 187.11 & 49.0 & 5.12 & 6.88 & 23.4 \\
\hline $28 X-8,26-28$ & 198.67 & 86.8 & 8.01 & 6.91 & 22.8 \\
\hline $29 X-5,65-67$ & 205.36 & 3.93 & 0.81 & 13.7 & 32.6 \\
\hline $31 X-5,31-33$ & 222.81 & 119 & 10.8 & 6.72 & 22.3 \\
\hline $32 X-1,67-69$ & 226.97 & 152 & 16.6 & 8.27 & 24.2 \\
\hline $33 X-1,62-64$ & 236.72 & 150 & 16.6 & 8.08 & 24.1 \\
\hline $34 X-3,3-5$ & 248.93 & 4.05 & 0.66 & 8.96 & 31.0 \\
\hline $35 X-1,76-78$ & 256.46 & 3.84 & 0.84 & 11.0 & 31.8 \\
\hline $36 \times-2,76-78$ & 266.72 & 18.5 & 2.57 & 8.00 & 24.0 \\
\hline $37 X-2,42-44$ & 277.22 & 3.29 & 0.64 & 13.8 & 33.6 \\
\hline $38 X-2,120-122$ & 287.80 & 3.32 & 0.60 & 9.9 & 33.4 \\
\hline $41 X-4,73-75$ & 319.73 & 5.35 & 1.08 & 10.9 & 31.9 \\
\hline $42 X-1,133-135$ & 325.53 & 21.1 & 3.34 & 9.7 & 29.5 \\
\hline $43 X-1,13-15$ & 333.83 & 4.66 & 0.77 & 14.0 & 33.2 \\
\hline $44 X-3,100-102$ & 347.20 & 4.83 & 1.31 & 13.8 & 29.4 \\
\hline $45 X-3,146-148$ & 357.16 & 4.18 & 0.76 & 12.2 & 34.3 \\
\hline $49 X-3,132-134$ & 392.42 & 15.6 & 8.63 & 53.8 & 70.0 \\
\hline $50 X-1,134-136$ & 399.44 & 19.4 & 10.6 & 50.8 & 67.0 \\
\hline $51 X-1,86-88$ & 408.56 & 5.08 & 1.24 & 11.0 & 33.7 \\
\hline $52 X-4,62-64$ & 422.52 & 9.3 & 1.91 & 11.9 & 31.6 \\
\hline $54 X-2,84-86$ & 437.31 & 109 & 17.8 & 13.2 & 37.0 \\
\hline $55 X-1,40-42$ & 445.30 & 17.3 & 2.40 & 8.65 & 26.1 \\
\hline $57 X-5,110-112$ & 470.50 & 151 & 18.8 & 9.7 & 27.1 \\
\hline $63 X-2,94-96$ & 520.64 & 85.1 & 11.3 & 8.45 & 24.5 \\
\hline $64 X-3,123-125$ & 531.33 & 16.2 & 1.80 & 7.13 & 24.6 \\
\hline $65 X-6,9-11$ & 544.39 & 5.74 & 1.21 & 12.5 & 31.3 \\
\hline $67 X-1,77-79$ & 556.87 & 6.13 & 1.03 & 9.5 & 30.3 \\
\hline $71 X-2,72-74$ & 596.12 & 2.49 & 0.53 & 9.9 & 29.3 \\
\hline $72 X-3,40-42$ & 606.00 & 2.77 & 0.54 & 12.8 & 32.4 \\
\hline $82 X-6,45-47$ & 695.53 & 5.01 & 1.03 & 10.7 & 33.5 \\
\hline $91 X-3,104-106$ & 769.69 & 2.99 & 0.83 & 14.8 & 33.2 \\
\hline
\end{tabular}

$M_{\mathrm{s}}=$ saturation magnetization, $M_{\mathrm{rs}}=$ saturation remanence, $H_{\mathrm{c}}=$ coercivity, $H_{\mathrm{cr}}=$ coercivity of remanence . 